\title{
INTERPRETASI AKUSTIK IMPEDANSI (AI) MENGGUNAKAN DATA SEISMIK DAN DATA SUMUR UNTUK MENENTUKAN ZONA PROSPEK HIDROKARBON
}

\author{
Hanum Eko Hapsari ${ }^{1 *}$, Intan Lestari ${ }^{2}$, Samsidar ${ }^{1}$ \\ ${ }^{1}$ Program Studi Fisika Fakultas Sains dan Teknologi Universitas Jambi \\ ${ }^{2}$ Program Studi Kimia Fakultas Sains dan Teknologi Universitas Jambi \\ Jl. Jambi-Ma. Bulian KM 15 Mendalo Darat Jambi 36361 \\ *E-mail korespondensi: hanumekohapsari@gmail.com
}

\begin{abstract}
Research has been conducted to determine the prospect of hydrocarbon zones using the interpretation of acoustic impedance (AI) seismic method in Field X, South Sumatra Basin, Jambi Province. The purpose of this study was to determine the AI value on the distribution map of AI values for hydrocarbon prospect zones in Field X. In this study the data used were 3D seismic data with PSTM (Post-Stack Time Migration) type, and well data. Data processing using Hampson and Russell (HRS) software used in the mining and petroleum fields has a function for subsurface modeling below the ground surface of reservoir characterization. Well data will be linked to seismic data so that the well data will be in the actual position. The distribution of hydrocarbon prospect zones in PEV-1 well can be seen first in crossplot analysis at a depth of 1760-1798 $m$ with AI cutoff value indicated as sandstone ranging from $8450(\mathrm{~m} \mathrm{~s})^{*}(\mathrm{~g} / \mathrm{cc})$ and above, with a high correlation value 0.818 time shift $0 \mathrm{~ms}$. Picking horizon is carried out to determine the target zone layer and its continuity laterally on seismic volume so that a model based can be done as an initial subsurface description below the soil surface at PEV-1 well. Then the next step is a post-stack analysis based model to find out how much the error value of the target zone prediction with certain parameters through the PEV-1 well data. So with a correlation value of 0.936429 and an error value of 0.35227 in the post-stack analysis model based, AI inversion in the PEV-1 well layer which is the target zone of the hydrocarbon prospect is indicated by the range of $8450(\mathrm{~m} / \mathrm{s}) *(\mathrm{~g} / \mathrm{cc})$ which is indicated as sandstone.
\end{abstract}

Keywords : seismic method, well data, reservoir, acoustic impedance.

\begin{abstract}
ABSTRAK
Telah dilakukan penelitian menentukan zona prospek hidrokarbon menggunakan interpretasi metode seismik akustik impedansi (AI) di Lapangan X, Cekungan Sumatera Selatan, Provinsi Jambi. Tujuan dari penelitian ini adalah untuk mengetahui nilai AI pada peta persebaran nilai AI untuk zona prospek hidrokarbon di Lapangan X. Pada penelitian ini data yang digunakan yaitu data seismik 3D dengan tipe PSTM (Post-Stack Time Migration), dan data sumur. Pengolahan data menggunakan software Hampson and Russell (HRS) yang digunakan dalam bidang pertambangan dan perminyakan yang memiliki fungsi untuk pemodelan subsurface di bawah permukaan tanah karakterisasi reservoir. Data sumur akan dikaitkan terhadap data seismik sehingga data sumur akan berada pada posisi yang sebenarnya. Persebaran zona prospek hidrokarbon di sumur PEV-1 dapat dilihat terlebih dahulu pada crossplot analysis di kedalaman 1760-1798 m dengan nilai cutoff AI diindifikasikan sebagai batu pasir berkisar $8450(\mathrm{~m} / \mathrm{s})^{*}(\mathrm{~g} / \mathrm{cc})$ keatas, dengan nilai korelasi yang tinggi 0.818 time shift 0 ms. Picking horizon dilakukan untuk menentukan lapisan zona target dan kemenerusannya secara lateral pada volume seismic sehingga dapat dilakukan model based sebagai gambaran awal subsurface di bawah permukaan tanah pada sumur PEV-1. Kemudian tahapan selanjutnya ialah post-stack analysis model based untuk mengetahui seberapa besar nilai error prediksi zona target dengan parameter tertentu melalui data sumur PEV-1. Sehingga dengan nilai korelasi sebesar 0.936429 dan nilai error-nya 0.35227 pada post-stack analysis model based, inversi AI pada sumur PEV-1 lapisan yang menjadi target zona prospek hidrokarbon ditunjukkan dengan range nilai $8450(\mathrm{~m} / \mathrm{s}) *(\mathrm{~g} / \mathrm{cc})$ yang diidikasikan sebagai batu pasir.
\end{abstract}

Kata kunci :metode seismik, data sumur, reservoar, impedansi akustik.

\section{PENDAHULUAN}

Keberadaan energi merupakan hal yang penting dan tidak bisa dilepaskan dari kehidupan manusia. Kondisi sumberdaya energi yang semakin berkurang sedangkan populasi penduduk terus mengalami peningkatan mengakibatkan kelangkaan 
energi, diantaranya migas (minyak bumi dan gas). Migas merupakan energi utama yang berperan penting dalam menopang keberlangsungan kegiatan industri baik dalam skala kecil ataupun besar, dan merupakan energi konvensional yang jika habis tidak dapat diperbaharui lagi. Kebutuhan migas selalu meningkat di masyarakat sesuai kebutuhan, sehingga perlu dilakukan eksplorasi hidrokarbon terus-menerus dengan berbagai metode diantaranya menggunakan metode seismik.

Survei seismik dilakukan untuk memetakan kondisi lapisan batuan di bawah permukaan yang diperoleh dengan mencatat gelombang pantulan getaran dari dalam tanah pada kedalaman tertentu dan direkam oleh alat pencatat penerima getaran. Metode seismik membutuhkan sumber energi sebagai sumber getarannya seperti dinamit, seismik vibrator, dan air gun. Metode yang digunakan untuk eksplorasi hidrokarbon yaitu seismik refleksi, telah digunakan untuk eksplorasi hidrokarbon sejak tahun 1920-an. Berdasarkan hasil studi geologi dan geofisika, suatu lokasi dinyatakan memiliki prospek migas bila memenuhi seluruh kriteria sistem hidrokarbon (petroleum system). Diantara interpretasi data seismik untuk menentukan prospek zona hidrokarbon yaitu interpretasi Impedansi Akustik (AI) [1].

Impedansi akustik didefinisikan sebagai sifat batuan yang dipengaruhi oleh jenis litologi, porositas, kandungan fluida, kedalaman, tekanan dan temperatur, sehingga dapat digunakan sebagai indikator litologi, porositas, hidrokarbon sampai dengan kuantifikasi karakter reservoar [2]. Data yang digunakan dalam eksplorasi hidrokarbon adalah data seismik dan data log sumur. Data seismik memberikan resolusi bawah permukaan secara horizontal dalam domain waktu, sedangkan data log sumur dapat memberikan resolusi secara vertikal dalam domain kedalaman.

Dalam penelitian ini untuk mengetahui zona prospek hidrokarbon menggunakan prinsip akustik impedansi model based dilakukan dengan metode seismik refleksi karena metode ini mempunyai kelebihan dapat memberikan informasi yang lebih lengkap dan baik mengenai keadaan struktur bawah permukaan. Selain itu, untuk mengetahui zona prospek hidrokarbon nilai AI menunjukkan hubungan yang berbanding terbalik dengan nilai porositas, sehingga jika nilai AI semakin kecil maka nilai porositas semakin besar [3].

Beberapa penelitian sebelumnya mengenai eksplorasi hidrokarbon menyatakan yaitu: pertama, penentuan zona prospek reservoir hidrokarbon pada tahap eksplorasi dengan analisis petrofisika formasi baturaja lapangan Z Blok Sekayu cekungan Sumatera Selatan pada kedalaman 4308 feet menghasilkan perhitungan yang relevan 18,46 ppm [4], kedua, karakterisasi reservoar menggunakan aplikasi seismik atribut dan impedansi akustik pada kedalaman 27000-34000 feet menghasilkan porositas 8-11\% prospek hidrokarbon yang merata [5], dan ketiga, analisa potensi migas dengan impedansi akustik seismik sphere spike menghasilkan nilai korelasi yang rendah dan impedansi yang rendah sekitar 9 dalam skala yang mengidentifikasikan gas [6]. Oleh karena itu peneliti tertarik melakukan pengolahan data seismik dan data sumur untuk menentukan zona prospek hidrokarbon dengan prinsip impedansi akustik model based, melihat bahwa impedansi akustik model based dapat digunakan sebagai indikator hidrokarbon dengan korelasi yang cukup baik.

\section{METODE}

Penelitian ini menggunakan data seismik 3D PSTM dan data sumur di Lapangan $X$, Cekungan Sumatera Selatan, Provinsi Jambi.

\section{Peralatan Penelitian}

Peralatan yang digunakan dalam penelitian yaitu Laptop/PC, Microsoft Excel, Sofware HRS. 


\section{Pengambilan Data}

Pengambilan data pada penelitian ini dilakukan dengan pengambilan data sekunder. Data sekunder yang akan digunakan yaitu data seismik dengan format *sgy dan data sumur dengan format *las.

\section{Pengolahan data}

Prosedur pengolahan data dimulai dengan menginput nilai yang didapat di dalam Microsoft Excel. Data dalam Microsoft Excel tersebut yaitu data seismik dan data sumur yang akan digunakan untuk pengolahan data dan interpretasi data menggunakan software HRS.

\section{Interpretasi Data}

Pada tahap interpretasi data yang akan dilakukan adalah menjelaskan nilai AI dari software HRS. Nilai AI dapat digunakan sebagai suatu indikator litologi, porositas, hidrokarbon, serta pemetaan litologi. Keberadaan gas bumi dalam batuan resevoir menyebabkan nilai AI yang lebih rendah, karena adanya gas bumi dapat menyebabakan turunnya kecepatan gelombang seismik dalam batuan.

\section{HASIL DAN PEMBAHASAN}

\section{Interpretasi Menggunakan Software HRS}

Hasil akhir dari suatu proses inversi seimik adalah berupa data akustik impedansi yang memiliki informasi lebih lengkap dibandingkan data seismik. Perubahan amplitudo pada data seismik hanyalah mencerminkan suatu bidang batas antar lapisan batuan sehingga bisa dikatakan bahwa data seismik adalah atribut dari suatu bidang batas lapisan batuan, sedangkan akustik impedansi mencerminkan sifat fisis batuan.

Harga akustik impedansi ini lebih dipengaruhi oleh kecepatan dibanding dengan densitas. Sebagai contoh variasi porositas pada batuan yang berisi fluida (misalnya gas pada batu pasir) mempunyai efek yang lebih signifikan pada log kecepatan dibandingkan dengan $\log$ densitas. Keberadaan gas bumi dalam batuan resevoar menyebabkan akustik impedansi yang lebih rendah, karena adanya gas bumi dapat menyebabakan turunnya kecepatan gelombang seismik dalam batuan.

Pantulan gelombang seismik terjadi disebabkan oleh perubahan akustik impedansi lapisan. Nilai kontras akustik impedansi dapat diperkirakan dari amplitudo refleksinya, semakin besar amplitudo refleksi maka semakin besar pula kontras akustik impedansi. Jadi, dapat dilihat bahwa data seismik melihat objek bawah permukaan dalam bentuk bidang batas antara lapisan-lapisan batuan, sedangkan akustik impedansi sebagai hasil inversi akan melihat objek bawah permukaan tersebut sebagai lapisannya itu sendiri. Sehingga tampilan akustik impedansi akan lebih mendekati dunia rill dan mudah dipahami.

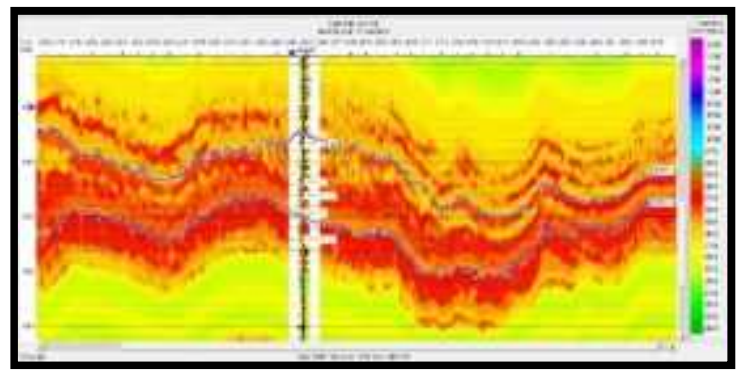

Gambar 1. Inversi Akustik Impedansi (AI).

Gambar 1 menjelaskan hasil gambaran litologi bawah permukaan di Lapangan $\mathrm{X}$. Inversi dilakukan dengan input yang digunakan adalah range inversion pada waktu $1100-2100 \mathrm{~ms}$, iterasi 10 , dan prewhitening $10 \%$. Volume akustik impedansi menunjukkan persebaran nilai dari akustik impedansi dengan range warna pada gambar berkisar 6000$12000(\mathrm{~m} / \mathrm{s})^{*}(\mathrm{~g} / \mathrm{cc})$. Rentang warna hijau ke ungu menunjukkan nilai akustik impedansi dari kecil ke besar.

Zona target dengan batas horizon 1 dan horizon 2 memiliki rentang warna kuning sampai merah yang memiliki kemiripan dengan $\log$ p-impedance. Kemiripan nilai AI 
dengan $\log$ p-impedance menunjukkan bahwa ketepatan perseberan zona prospek hidrokarbon. Hubungan akustik impedansi dengan porositas mempunyai hubungan berbanding terbalik [7].

Berdasarkan hasil inversi akustik impedansi pada sumur PEV-1 lapisan yang menjadi target zona prospek hidrokarbon ditunjukkan dengan range high impedance $8450 \quad(\mathrm{~m} / \mathrm{s})^{*}(\mathrm{~g} / \mathrm{cc}) \quad$ keatas yang diidentifikasikan sebagai batu pasir. Persebaran batu pasir dapat dilihat dari peta persebaran inversi akustik impedansi dengan persebaran yang baik secara lateral pada Gambar 2.

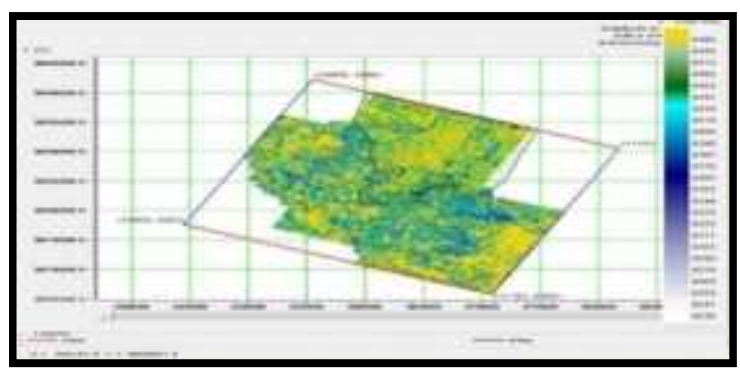

Gambar 2. Peta Persebaran Inversi Akustik Impedansi.

Pada Gambar 2, persebaran zona prospek hidrokarbon ditunjukkan dengan warna hijau dan kuning yang meliputi sumur PEV-1. Penentuan hidrokarbon selain melakukan pemetaan AI terdapat data pendukung lainnya, yaitu data DST (drill steam test) dan petrofisika.

\section{KESIMPULAN}

Pada penelitian yang dilakukan pada Lapangan $\mathrm{X}$ menggunakan metode seismik inversi akustik impedansi maka didapat kesimpulan sebagai berikut:Prospek hidrokarbon di Lapangan X pada formasi air benakat merupakan batu pasir dengan kedalaman 1760-1798m.Hubungan antara nilai AI dan porositas batu pasir berbanding terbalik, dengan nilai cutoff porositas batu pasir berada di bawah $0.300 \%$.Prospek hidrokarbon berada pada nilai cutoff AI dengan range $8450(\mathrm{~m} / \mathrm{s})^{*}(\mathrm{~g} / \mathrm{cc})$ keatas berdasarkan data crossplot dan peta slice pada lapisan target nums-2.

\section{REFERENSI}

1. Sanny, T. A. (2004). Metode Seismik Refleksi. Bandung: Institut Teknologi Bandung.

2. Nigel, A. (2013). Seismic Interpretation : The Physical Aspects. German : Springer Science Business Media.

3. Kanai, K. (1983). Seismology in Engineering. Japan: Tokyo University.

4. Septianingrum, R., dkk. (2014). Penentuan Zona Prospek Reservoir Hidrokarbon pada Tahap Eksplorasi dengan Analisis Petrofisika Formasi Baturaja Lapangan Z Blok Sekayu Cekungan Sumatera Selatan

5. Nur, M., dkk. (2017). Karakterisasi Reservoar menggunakan Aplikasi Seismik Atribut dan Inversi Seismik Impedansi Akustik Studi Kasus Lapangan Teapot Dome Wyoming. Surabaya : ITS.

6. Miharno, F. (2016). Analisa Potensi Minyak dan Gas Bumi dengan Atribut Seismik pada Lapangan X Cekungan Sumatera Selatan. Yogyakarta : STTNAS.

7. Arifien, H. (2010). Inversi Seismik Berbasik Model untuk Karakterisasi Reservoir. Semarang :Universitas Diponegoro. 